\title{
Analysis of Nursing Care Concept: Perspective of the Person Submitted to Care
}

\author{
Camila Brasil Moreira, Ana Fátima Carvalho Fernandes, Míria Conceição Lavinas Santos, \\ Altamira Mendonça Félix Gomes, Carla Monique Lopes Mourão, \\ Rosy Denyse Pinheiro de Oliveira, Angelica Isabely de Morais Almeida, \\ Suzy Ramos Rocha, Cláudia Rayanna Silva Mendes, Sadrine Maria Eufrasino de Pinho, \\ Marinna Maria de Andrade Costa, Jordana Prado Benevides, \\ Caroline Batista de Queiroz Aquino, Iarlla Silva Ferreira, Raquel Vilanova Araujo \\ Department of Nursing, Federal University of Ceará, Fortaleza, Brazil \\ Email: camilabrasil@alu.ufc.br
}

Received 16 May 2016; accepted 19 June 2016; published 22 June 2016

Copyright (C) 2016 by authors and Scientific Research Publishing Inc. This work is licensed under the Creative Commons Attribution International License (CC BY). http://creativecommons.org/licenses/by/4.0/

cC) (i) Open Access

\begin{abstract}
This study aimed to analyze the concept of nursing care to patients with breast cancer on chemotherapy treatment, according to the perspective of the person submitted to care. The study followed the conceptual analysis methodology proposed by Walker and Avant according to Waldow, and it was developed through consultation to SCOPUS and CINAHL databases. The selection was carried out by inclusion and exclusion criteria, constituting a sample of 7 articles. There have been identified the main uses of the risk concept, defining attributes, antecedents and consequences of the concept. The evaluation of the concept and nursing care to breast cancer patient on chemotherapy treatment allowed a broader understanding of the phenomenon, with emphasis on the skills and competencies in nursing care dispensed to woman on chemotherapy treatment for breast cancer.
\end{abstract}

\section{Keywords}

Nursing, Breast Neoplasms, Analysis, Research, Nursing Care, Chemotherapy

\section{Introduction}

Human beings with their biopsychosocial needs are essentially a being who needs care. The act of care aims to promote complete well-being and sets up an attitude of care, responsibility, zeal and involvement between the caregiver and the one being cared [1].

Caring is an attitude and it is related to various acts. The care is intrinsic to the human being and its concept is 
related to the meaning of the Latin word cogitátu, which means reflection, thought, thinking, paying attention, showing interest, revealing an attitude, a concern [2]. Thus, care means attitude and attention link with others and with himself. Caring means having care attitudes, i.e. attention for each other in order to suppress our needs.

That care, in turn, is the focus of nurses' actions and needs to be better respected and understood by all the subjects involved in the process of caring (professional and patient). Thus, from the end of the 70's, care has been discussed and became an object of study of many researches developed by nursing professionals [3].

Research shows that women with breast cancer undergoing chemotherapy treatment manifest clinical morbidities caused directly by the disease state, as well as the influences of the disease and therapies, generating interference on her quality of life regarding her everyday activities and satisfaction with life. Studies that evaluated aspects of quality of life of these women in an attempt to formulate intervention strategies, in order to minimize the effects of the disease and treatments of progressive character, as well as increase the aspects of quality of life, identified that the care provided to women with breast cancer is one of the key aspects to be considered [4]-[6].

Thus, the study aims to analyze the concept of nursing care to patients with breast cancer on chemotherapy treatment, according to the perspective of the person submitted to care.

\section{Methods}

The analysis of the concept of nursing care was performed using steps of the methodology proposed by Walker and Avant, where the following steps are applied: selection of the concept; determination of the goals of conceptual analysis; identification of possible uses of the concept; determination of critical or essential attributes and antecedent and consequent events of the concept [7].

The research on the analysis of the concept may have as objectives: to clarify the meaning of a concept, to develop an operational definition and to add/renew an existing theory, among others [8]. In the present study, the analysis of the concept of nursing care had as purpose the clarification of this phenomenon in the Nursing field, specifically, in the themes about breast cancer and chemotherapy, aiming to contribute with subsidies that could serve as a basis for future research within these areas.

To identify the various uses of the concept of nursing care, there were used journal articles obtained by consulting the Scopus and Cumulative Index to Nursing and Allied Health Literature (CINAHL) databases, because these are comprehensive bases of research related to Nursing. The pursuit of studies was carried out through the use of these controlled descriptors (MEsH): breast neoplasms and nursing care.

There were established the following criteria for the inclusion of articles in the study: it is written in English, Portuguese or Spanish; it has association with the guiding questions: what are the definitions found on nursing care? What is the importance of the concept of nursing care for Nursing within the topics of breast cancer and chemotherapy? We decided to exclude from the search items that did not address the topic relevant to the scope of the purpose of the study, studies of editorial type and letters to the editor.

Initially, there were identified 332 articles in the sources described. First, we have read the summaries to confirm if they had elements that would serve as a basis for the conceptual analysis. As a result of this preliminary analysis, 35 articles were read in their entirety. Thus, the final sample of the survey was composed of 7 articles [9]-[15].

In this way, we have proceeded to a careful and objectified reading of the articles that formed the basis for the concept analysis, highlighting the excerpts that corresponded to the elements of interest, namely that referred to the critical or essential attributes, the antecedent and consequent events of nursing care.

The defining attributes, also called critical attributes, are characteristics that act as elements for differential diagnosis, that is, to discriminate what is an expression of the concept of what is not. Attributes can vary according to the context in which they are inserted and, therefore, those that are more often associated with the concept must be identified, in the most different possible contexts [7].

The identifications of the antecedents and consequences of the concept are the surveys of incidents or events that happen prior and subsequent to the phenomenon, respectively. However, they can coincide or not with the attributes defined [8]. The conception and analysis of nursing care in the perception of the person being cared was considered according to Waldow [16].

\section{Results and Discussion}

After the survey, we have identified that nursing care is a concept present in various Nursing research related to 
breast cancer. When we choose to specify this care to the patient on chemotherapy, it was observed that this concept is generally found in works which objectives are geared to interventions on the effects caused by the treatment and its adverse reactions.

Nursing care conception can be obtained in three areas: in the perspective of the nurse, in the perspective of the person being cared and in the perspective of the caregiver [16]. The perception of care by the nurse and the caregiver are essential, so the implementation of the care is carried out efficiently and effectively [18]. However, when it scales the transcendence of the perception of care by the one who receives care, an overview of various aspects can be seen, to be evaluated by the account of the individual to be cared, what makes this understanding essential for the proper prescription of care according to his/her needs, as referred to by the patient [17].

Thus, the studies highlight the need for nurses, in order to increase the efficiency of care to this specific population, to develop a model that can predict individual nursing care to the patient with breast cancer on chemotherapy treatment, to promote a selection of care plan identifying the health aspects to be observed, so that care can satisfy the needs of these patients.

Some studies have identified that it is important that all healthcare professionals, in particular the nurses, evaluate nursing care to the patient with breast cancer on chemotherapy treatment because they realized that adherence to cancer treatments is directly related to the care provided to the patient throughout its process [17].

We have also identified that the evaluation of nursing care to the patient with breast cancer on chemotherapy can be a useful intervention to increase participation of nurses in care prescription regarding cancer treatments. Educational programs to inform about the effects and side effects of chemotherapy, and how to perform its management, should be offered to those who will undergo the treatment of breast cancer, after evaluation of nursing care.

\section{Defining Attributes, Antecedents and Consequences}

After the identification of the uses of the concept, we sought to determine the critical or essential attributes, antecedents and consequences of the concept of nursing care [3], in the themes of breast cancer and chemotherapy described by the authors of the articles analyzed.

Human care permeates the action of several health-related professions, but its uniqueness lies in nursing, since it means the essence of this profession. So, the nursing care must be analyzed, understood and reframed within the context of breast cancer and chemotherapy, because it is a health condition that generates feeling of anguish, fear and impotence, and its treatment causes to the individual a break from her usual environment, amending customs, habits, the ability of self-realization and personal care [7].

An attribute considered relevant to the concept of nursing care to the patient with breast cancer on chemotherapy is related to the observation and appreciation of the signs and symptoms caused by the treatment. Women referred to a sense of awareness of these effects by healthcare professionals, but there is often a short resolution of the services and the identification of its occurrence does not happen at the beginning of its appearance, being later, which makes it increasingly remote the chance to stop or minimize the consequences caused [8].

The meaning of care permeates the way to take care of patients, from the dialogue. When the nurse tells in detail that there is a special way to be dealing with each of the complaints, doubts and fears, women bring a perspective of feeling comfortable and safe by the implemented treatment [11].

Safety is mentioned in the sense of confidence, where feeling safe, trusting the person and what they were doing, permeates the relationship of feeling comfortable. Feeling at ease arises when no problems are featured in technical skill and it generates for women the perception that the nurse is attentive, good-tempered and has a good relationship with the team [13].

Technical care runs through the eyes of patients in order to intertwine it with intrinsic aspects of the feelings provided to them by carrying out the technique to be performed. The technical competence is closely related to safety, where the cordiality and attention are characteristic that should be inherent to the oncological treatment provided by nurses, primarily in the outpatient environment, since it is an environment where the patient is integrated, where interactions and transactions of more intensive care happen and where the person can be satisfied as being cared [8].

Women on chemotherapy realize that nursing professionals utilize technical competence, specific scientific knowledge of the treatment, in addition to show empathy to understand the human being about what the patient and/or the family are experiencing in a cancer clinic. 
Another attribute considered important to the concept of nursing care to the patient with breast cancer on chemotherapy is the dependency, a term often used in the literature, applied towards dependent state, subjection and subordination. Derived from the Latin verb "pendere", it means "depend on (passive sense), be attached (active sense)" [16].

The dependence on nursing care for chemotherapy for women with breast cancer is not related to the existence of a particular active sense, as can be noticed in reading the articles. But the likelihood of the emergence of dependency situations in the passive sense generates undesirable situations during nursing care process based on the involvement of the woman not feeling able to take any active role in her healthcare. This relationship is due to a number of factors. Thus, promoting independence is, first of all, cause the patient becomes active, i.e. anticipate the management of symptoms before its appearance in those women defined as dependent [15]. The perception of this feeling is not considered nice.

Some studies show that dependence as a nursing care is often related to lack of knowledge offered by the healthcare professionals, including nurses, about illness, treatments and their effects [17]. Knowing how to listen, knowing "to be with", the caring for the other, is a feeling perceived by women with breast cancer. They perceive the efforts of nurses in encouraging them and keeping them informed, but also promoting other strategies to control anxiety and malaise generated during the infusion of antineoplastic [14].

The professional performance is perceived as the nurse trying to act so as to provide relief to the patient, explaining the procedures that will be carried out and looking for ways to facilitate the verbalization of feelings, fears, concerns, anxieties, doubts and expectations [17].

In the articles analyzed, we identified three consequences of the nursing care to the patient with breast cancer on chemotherapy: anxiety relief; need for attention and development of strategies for emotional support.

The first consequence considered important in the analysis was the anxiety relief, where it was noticed that the nurse promoted psychological support, perceived by the patients as an important factor of humanization, since it identifies their concerns, anxieties and fears, guiding them. Having the opportunity to live with these patients, therefore, experiencing with them their pain and suffering, and consequently establishing greater bond with human frailty [19].

The relief is delivered through careful and calm conduct, where the nurse can help women to reduce anxiety during chemotherapy, since their fears may influence the therapy and compromise the health promotion process [16].

Another consequent result is the need of attention that is interpreted as being stand next to someone, showing that there is caring, whether through a look, affection, sensitive listening, and it qualifies the relationship with the nurse [20] [21]. In this perspective, the nursing care is made possible by the exercise of solidarity and sensitivity of the professional regarding the needs of the patient in treatment.

The third assigned consequence is the development of strategies for emotional support. Healthcare providers, particularly nurses, should develop specific strategies for managing stress arising from antineoplastic treatment, counseling to deal with breast cancer and the effects caused by chemotherapy.

Women should receive emotional support and learn to identify the signs and symptoms that may arise during and after chemotherapy, so they can start the management of these effects more effectively [14].

Understanding, yet, the reports reviewed, there is visibility of the nurse as an obfuscated professional, because the use of the expression that name the nurse presents a marked confusion of functions, since it leads to confuse more than one person on the team, and in the chemotherapy sectors there is only one nurse per shift. However, when we performed the analysis of the perceptions of women with breast cancer undergoing chemotherapy, we distinguished the accounts for the nurse, so the concept does not present bias.

\section{Conclusions}

The results of the conceptual analysis of nursing care to the patient with breast cancer on chemotherapy treatment pointed implications, allowing to nursing professionals an understanding about the importance of the work of these professionals in the treatment for breast cancer.

The nurse should be an important participant with their comments and appreciation of signs and symptoms, which can arise during the course of treatment, thereby providing quality care in which the patient can feel safe in each stage of the treatment.

The ability to interact with the patient together with the technical skill of the nurse awakens feelings of safety and trust, reflecting in the welfare of patients and family members who accompany the treatment. 
The development of human skills by nurses reflects in the nursing care, as it allows patients to empower themselves for self-care away from the state of total dependence, which is an unpleasant feeling reported by patients in the articles analyzed.

In this way, with the analysis of the articles, we identified that the nursing care goes beyond technical care involving also the relief of anxiety, the exercise of solidarity and the development of strategies for the patient's emotional support.

\section{References}

[1] Fernandes, M.A., Evangelista, C.B., Platel, I.C.S., Agra, G., Lopes, M.S. and Rodrigues, F.A. (2013) Percepção dos enfermeiros sobre o significado dos cuidados paliativos em pacientes com câncer terminal. Ciência \& Saúde Coletiva, 18, 2589-2596. http://dx.doi.org/10.1590/S1413-81232013000900013

[2] Reigada, C., et al. (2014) O Suporte à Família em Cuidados Paliativos/Family Support in Palliative Care. Textos \& Contextos (Porto Alegre), 13, 159-169. http://dx.doi.org/10.15448/1677-9509.2014.1.16478

[3] Vale, E.G. and Pagliuca, L.M.F. (2011) Construção de um conceito de cuidado de enfermagem: Contribuição para o ensino de graduação. Revista Brasileira de Enfermagem, 64, 106-113. http://dx.doi.org/10.1590/S0034-71672011000100016

[4] Lôbo, S.A., Fernandes, A.F.C., de Almeida, P.C., de Lima Carvalho, C.M. and Sawada, N.O. (2014) Qualidade de vida em mulheres com neoplasias de mama em quimioterapia. Acta Paulista de Enfermagem, 27, 554-559. http://dx.doi.org/10.1590/1982-0194201400090

[5] Kameo, S.Y., Silva, G.M., Sawada, N.O. and de Santana, M.E. (2015) Febrile Neutropenia Recurrence after Chemotherapy in Patients with Breast Cancer. Revista de Enfermagem da UFPI, 4, 111-118.

[6] Frazão, A. and Skaba, M.M.F.V. (2013) Mulheres com câncer de mama: As expressões da questão social durante o tratamento de quimioterapia neoadjuvante. Revista Brasileira de Cancerologia, 59, 427-435.

[7] Walker, L.O. and Avant, K.C. (1995) Concept Development. In: Walker, L.O. and Avant, K.C., Eds., Strategies for Theory Construction in Nursing, 3rd Edition, Appleton \& Lange, Norwalk, 35-78.

[8] Da Silva, A.P.S., Galvao, C.M., Fernandes, A.F.C. and Lopes, M.V.O. (2011) Conceito de risco para câncer de mama em pesquisas de enfermagem. Acta Paulista de Enfermagem, 24, 834-838. http://dx.doi.org/10.1590/s0103-21002011000600018

[9] Cereijo, C., Bazarra, A., Acea, B., González, C., López, S. and Candía, B. (2005) Atención de enfermería a pacientes con cáncer de mama en cirugía mayor ambulatoria. Enfermería Clínica, 15, 106-110. http://dx.doi.org/10.1016/S1130-8621(05)71091-3

[10] Rustøen, T., Gaardsrud, T., Leegaard, M. and Wahl, A.K. (2009) Nursing Pain Management—A Qualitative Interview Study of Patients with Pain, Hospitalized for Cancer Treatment. Pain Management Nursing, 10, 48-55. http://dx.doi.org/10.1016/j.pmn.2008.09.003

[11] Funghetto, S.S., Terra, M.G. and Wolff, L.R. (2003) Mulher portadora de câncer de mama: Percepção sobre a doença, família e sociedade. Revista Brasileira de Enfermagem, 56, 528-532. http://dx.doi.org/10.1590/S0034-71672003000500012

[12] Costa, W.B., Vieira, M.R.M., Nascimento, W.D.M., Pereira, L.B. and Leite, M.T.D.S. (2012) Mulheres com câncer de mama: Interações e percepções sobre o cuidado do enfermeiro. Revista Mineira de Enfermagem, 16, 31-37.

[13] Billhult, A., Stener-Victorin, E. and Bergbom, I. (2007) The Experience of Massage during Chemotherapy Treatment in Breast Cancer Patients. Clinical Nursing Research, 16, 85-99. http://dx.doi.org/10.1177/1054773806298488

[14] Alcântara, L.F.F.L.D., Malveira, E.A.P. and Beque, G.V.D. (2004) Enfermeiras cuidando em oncologia ambulatorial: A consulta de enfermagem e o sentido do cuidar. Revista Enfermagem UERJ, 12, 259-264.

[15] Fontes, C.A.S. and Alvim, N.A.T. (2008) A relação humana no cuidado de enfermagem junto ao cliente com câncer submetido à terapêutica antineoplásica. Acta Paulista de Enfermagem, 21, 77-83. http://dx.doi.org/10.1590/S0103-21002008000100012

[16] Waldow, V.R. (2004) O cuidado na saúde: As relações entre o eu, o outro e o cosmo. Vozes, Petrópolis.

[17] Burille, A., Soares, L.C., Antonacci, M.H., Santana, M.D.G. and Schwartz, E. (2013) Manejo e enfrentamento dos efeitos adversos pelos clientes em tratamento quimioterápico. Ciência, Cuidado e Saúde, 7.

[18] Christovam, B.P., Porto, I.S. and De Oliveira, D.C. (2012) Gerência do cuidado de enfermagem em cenários hospitalares: A construção de um conceito. Revista da Escola de Enfermagem da USP, 46, 734-741. http://dx.doi.org/10.1590/S0080-62342012000300028

[19] Ribeiro, J.S. (1995) Dependência ou dependências? Incidências históricas na formalização dos conceitos. Toxicode- 
pendêcias, 3, 5-16.

[20] Acioli, S., David, H.M.S.L. and de Araujo Faria, M.G. (2012) Health Education and Nursing in Public Health: Reflections on Practice. Enfermagem UERJ, 20, 533-537.

[21] Gozzo, T.D.O., Lopes, R.R., Prado, M.A.S., Cruz, L.A.P.D. and Almeida, A.M.D. (2012) Informações para a elaboração de um manual educativo destinado às mulheres com câncer de mama. Escola Anna Nery, 16, 306-311, US Patent No. 821393. http://dx.doi.org/10.1590/S1414-81452012000200014

\section{Submit or recommend next manuscript to SCIRP and we will provide best service for you:}

Accepting pre-submission inquiries through Email, Facebook, Linkedin, Twitter, etc A wide selection of journals (inclusive of 9 subjects, more than 200 journals)

Providing a 24-hour high-quality service

User-friendly online submission system

Fair and swift peer-review system

Efficient typesetting and proofreading procedure

Display of the result of downloads and visits, as well as the number of cited articles

Maximum dissemination of your research work

Submit your manuscript at: http://papersubmission.scirp.org/ 